\title{
網目状構造物の効率的境界要素腐食解析*
}

\author{
青木 繁*1, 天谷賢 治*2, 今 森 智 史*3
}

\section{Effective Boundary Element Corrosion Analysis of Net Structure}

\author{
Shigeru AOKI ${ }^{* 4}$, Kenji AMAYA and Satoshi IMAMORI \\ ${ }^{* 4}$ Department of Computational Science and Engineering, Toyo University, \\ 2100 kujirai, Kawagoe, Saitama, 350-8585 Japan
}

\begin{abstract}
An efficient boundary element method is proposed for three-dimensional corrosion analysis of structures having net geometory, such as rebars in a reinforced concrete structure and a guard fence for a sea-side structure. The proposed method is based on the Fourier series expansion of boundary quantities, i.e., potential and current density, in the circumferential and axial directions of a net structure. It is possible for the new method to reduce largely an enormous number of elements which would be necessary in the conventional method to discretize the structures having net geometory. In order to demonstrate the usefulness of the proposed method, a couple of example problems of rebars in a concrete structure with a cathodic protection system are presented.
\end{abstract}

Key Words: Boundary Element Method, Corrosion Analysis, Potential, Current Density, Net Structure

\section{1. 緒}

網目状構造物は鉄筋コンクリートの鉄筋や取水口の 防護フェンス等, いろいろな構造物の一部を構成する ことが多い.これらの構造物の腐食を予測したり, 防 食システムを設計するために数值解析を利用すること が考えられる.

一般に, 腐食解析では, 構造物や部材表面の電流密 度および電位の分布を把握することが重要である.そ のため腐食解析には解析領域内部の要素分割を必要と

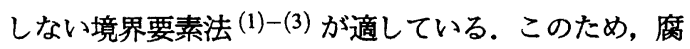
食解析への境界要素法の適用に関して多くの研究がな されてきた. (4)-(9)

しかし, 上記の網目状構造物に境界要素法を適用し ようとすると, 䖉大な要素数が必要となる. この困難 を軽減するために, 本研究では網目特有の電位および 電流密度分布を表わすことのできる特殊な要素 (以後, 網目要素と呼ぶ) を開発する. また, 従来法との比較 によりその精度を検証し，鉄筋コンクリート柱の腐食 解析を行うことによって本研究の有効性を示す.

* 原稿受付 2005 年 9 月 12 日.

*1 正員, 東洋大学工学部 (画350-8585 川越市鯨井 2100).

$* 2$ 正員, 東京工業大学情報理工学研究科.

*3 東京工業大学工学部.

E-mail : saoki@eng.toyo.ac.jp

\section{2. 基 磷 式}

図1のように土塞, コンクリート, 海水など (以下 では, 溶液と呼ぶ)が占める領域を $\Omega$ とする. この領 域におけるイオンの蓄積または損失が無視できると仮 定すると, 領域 $\Omega$ 内の電流密度 $i$ は次式を満足する.

$$
\operatorname{div} \boldsymbol{i}=0
$$

またオームの法則により, 電流密度 $i$ と電位 $\phi$ の間に は次の関係がある.

$$
i=-\kappa \operatorname{grad} \phi
$$

ここで, $\kappa$ は溶液の電気伝導度である. 式 (1) と (2)か ら，кが一定であると仮定すると，次のラブラス方程 式が導かれる.

$$
\nabla^{2} \phi=0
$$

溶液を囲む面上の境界条件は, 金属部表面 (図 1 の $\left.\Gamma_{m}\right)$ 上では

$$
\phi=-f(i)
$$

と表すことが出来る. ここで, $i$ は $\boldsymbol{i}$ の長さ (すなわち, $i=|i|)$ であり, $f(i)$ は分極曲線と呼ばれる, あらかじ め実験で得られる関数である. 電位 $\phi$ は金属に対する 溶液の電位であり，実験でよく用いられる，溶液に対 する金属の電位 $E$ とは, $\phi=-E$ という関係がある. 金属部表面以外では, 一般的なディレクレ (電位指定, 
図 1 の $\Gamma_{d}$ ) またはノイマン (電流密度指定, $\Gamma_{n}$ ) 条件 が境界条件として与えられる. 腐食速度は電流密度に 比例するので, 腐食解析は式 (3) を上記の境界条件の 下で解くことに帰着される.

通常の境界要素法の定式化に従えば, 式 (1) から次 式で表される境界積分方程式が導かれる。(3)

$$
\begin{aligned}
\kappa c \phi(\boldsymbol{y}) & =\int_{\Gamma} \phi^{*}(\boldsymbol{x}, \boldsymbol{y}) i(\boldsymbol{x}) d \Gamma(\boldsymbol{x}) \\
& -\int_{\Gamma} i^{*}(\boldsymbol{x}, \boldsymbol{y}) \phi(\boldsymbol{x}) d \Gamma(\boldsymbol{x})
\end{aligned}
$$

ここで， $x$ および $y$ はそれぞれ観測点とソース点であ り, $c$ は次式で表される定数である.

$$
c=\frac{\alpha}{4 \pi}
$$

ただし， $\alpha$ はソース点 $\boldsymbol{y}$ における境界の立体角を表す。 $\phi^{*}$ は 3 次元ラブラス方程式の基本解であり, $r$ をソー ス点と観測点の間の距離, すなわち $r=|\boldsymbol{x}-\boldsymbol{y}|$ とする と, 次式で与えられる.

$$
\phi^{*}(\boldsymbol{x}, \boldsymbol{y})=\frac{1}{4 \pi r}
$$

また, $i^{*}$ は基本解 $\phi^{*}(\boldsymbol{x}, \boldsymbol{y})$ の境界外向き単位法線方向 微分保数であり, 次式のように表される。

$$
\boldsymbol{i}^{*}(\boldsymbol{x}, \boldsymbol{y}) \equiv \kappa \frac{\partial \phi^{*}(\boldsymbol{x}, \boldsymbol{y})}{\partial \boldsymbol{n}}
$$

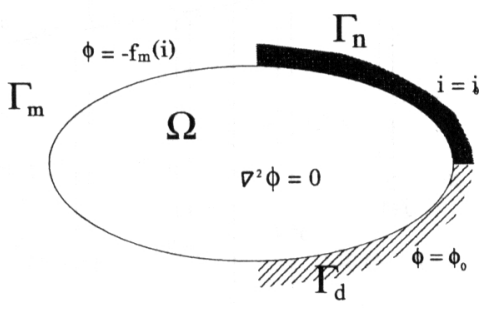

Fig. 1 Boundary conditions

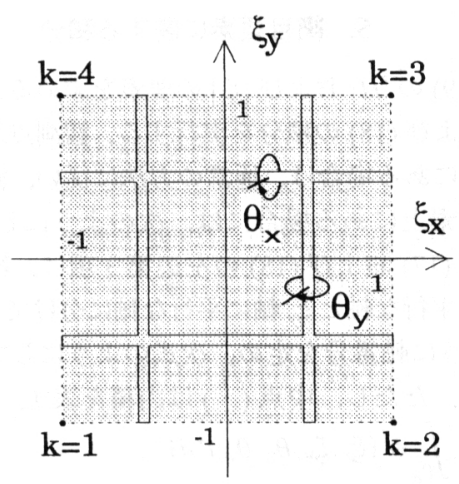

Fig. 2 Net element

\section{3. 網目要素の導入}

網目状構造物の表面を $\Gamma_{a}$ とし， $\Gamma_{a}$ を図 2 に示すよ うな 4 角形の網目要素を用いて離散化することを考元 る. 網目要素内では局所座標系 $\left(\xi_{x}, \xi_{y}\right)$ を採用し, 網 目を構成する軸の周方向に $\theta_{x}$ および $\theta_{y}$ をとる. 要素 $e$ 内の電流密度を次のように表す。

1. $\xi_{x}$ 軸に平行な軸の電流密度

$$
\begin{array}{r}
i_{x}^{e}\left(\xi_{x}, \xi_{y}, \theta_{x}\right)=\sum_{k=1}^{4} \Psi^{k} I_{e}^{k}+Q_{e}^{1}\left(-1-(-1)^{n} \cos n \xi_{x} \pi\right) \\
+Q_{e}^{3} \cos \theta_{x}+Q_{e}^{4} \sin \theta_{x}
\end{array}
$$

2. $\xi_{y}$ 軸に平行な軸の電流密度

$$
\begin{array}{r}
i_{y}^{e}\left(\xi_{x}, \xi_{y}, \theta_{y}\right)=\sum_{k=1}^{4} \Psi^{k} I_{e}^{k}+Q_{e}^{2}\left(-1-(-1)^{m} \cos m \xi_{y} \pi\right) \\
+Q_{e}^{5} \cos \theta_{y}+Q_{e}^{6} \sin \theta_{y}
\end{array}
$$

ここで, 内挿関数 $\Psi^{k}(k=1,2, \ldots, 4)$ はそれぞれ

$$
\begin{aligned}
& \Psi^{1}=\frac{1}{4}\left(1-\xi_{x}\right)\left(1-\xi_{y}\right) \\
& \Psi^{2}=\frac{1}{4}\left(1+\xi_{x}\right)\left(1-\xi_{y}\right) \\
& \Psi^{3}=\frac{1}{4}\left(1+\xi_{x}\right)\left(1+\xi_{y}\right) \\
& \Psi^{4}=\frac{1}{4}\left(1-\xi_{x}\right)\left(1+\xi_{y}\right)
\end{aligned}
$$

である. $m$ は一つの網目要素内に存在する $\xi_{x}$ に平行 な軸の本数であり, $n$ は $\xi_{y}$ に平行な軸の本数である. $I_{e}^{k}$ は, 網目要素 $e$ の 4 つ角における仮想的な節点值 (実際の節点は後述するように網目の各軸上にある)で ある.また, $Q_{e}^{1}$ および $Q_{e}^{2}$ は網目の軸に沿った方向の 周期変化を表現する未知数であり, $Q_{e}^{3} \sim Q_{e}^{6}$ は軸の周 方向の周期変化を表現する未知数である.

今回は周方向の電流密度分布の表現に 1 次のフーリ エ級数を用いたが, 若干の補足により 2 次以上のフー リエ級数を用いる(8) ことも可能である. 逆に, 軸に 沿った方向や周方向の電流密度の変化が線形変化に比 べ小さいことが予想される場合は，それらの変化がな い網目要素を用いることも可能である.

網目形状以外の金属部材に対しては非線形の分極曲 線をそのまま用いるが, 網目形状の金属に対しては, 本報では分極曲線を $\phi=a i+b(a$ および $b$ は定数 $)$ のよ うに直線近似した分極曲線を用いることとする. 従っ て, 網目要素上の電位は以下のように表される.

1. $\xi_{x}$ 軸に平行な軸の電位

$$
\begin{array}{r}
\phi_{x}^{e}\left(\xi_{x}, \xi_{y}, \theta_{x}\right)=a\left\{\sum_{k=1}^{4} \Psi^{k} I_{e}^{k}\right. \\
+Q_{e}^{1}\left(-1-(-1)^{n} \cos n \xi_{x} \pi\right) \\
\left.Q_{e}^{3} \cos \theta_{x}+Q_{e}^{4} \sin \theta_{x}\right\}+b
\end{array}
$$


2. $\xi_{y}$ 軸に平行な軸の電位

$$
\begin{aligned}
& \phi_{y}^{e}\left(\xi_{x}, \xi_{y}, \theta_{y}\right)=a\left\{\sum_{k=1}^{4} \Psi^{k} I_{e}^{k}\right. \\
& +Q_{e}^{2}\left(-1-(-1)^{m} \cos m \xi_{y} \pi\right) \\
& \left.+Q_{e}^{5} \cos \theta_{y}+Q_{e}^{6} \sin \theta_{y}\right\}+b
\end{aligned}
$$

以下では, 網目要素上の電流密度および電位を $i\left(\xi_{x}, \xi_{y}, \theta_{x}, \theta_{y}\right)$ および $\phi\left(\xi_{x}, \xi_{y}, \theta_{x}, \theta_{y}\right)$ という記号を用 いる. これらは， $\xi_{x}$ に平行な軸に関する場合はそれぞ れ式(9)および(15)を， $\xi_{y}$ 軸に平行な軸に関する場合 はそれぞれ式 (10)および (16) を表すとする.

\section{4. 境界糟分方程式の離散化}

網目形状部の境界 $\Gamma_{a}$ では網目要素を $n_{a}$ 個用いて, 網目形状部以外の境界 $\Gamma_{o}$ では要素内では通常要素 $($ 一 定要素) を $n_{o}$ 個用いて, 境界積分方程式 (5) を離散化 すると次式が得られる.

1.ソース点が網目要素上にある場合

$$
\begin{array}{r}
\kappa c^{i} \phi^{i}\left(\xi_{x}, \xi_{y}, \theta_{x}, \theta_{y}\right)+\sum_{j=1}^{n_{o}} \phi^{j} \int_{\Gamma_{o}^{j}} i^{*} d \Gamma \\
+\sum_{k=1}^{n_{a}} \int_{\Gamma_{a}^{k}} \phi^{k}\left(\xi_{x}, \xi_{y}, \theta_{x}, \theta_{y}\right) i^{*} d \Gamma \\
=\sum_{j=1}^{n_{o}} i^{j} \int_{\Gamma_{o}^{j}} \phi^{*} d \Gamma+\sum_{k=1}^{n_{a}} \int_{\Gamma_{a}^{k}} i^{k}\left(\xi_{x}, \xi_{y}, \theta_{x}, \theta_{y}\right) \phi^{*} d \Gamma
\end{array}
$$

\section{2.ソース点が通常要素上にある場合}

$$
\begin{aligned}
\kappa c^{i} \phi^{i} & +\sum_{j=1}^{n_{o}} \phi^{j} \int_{\Gamma_{o}^{j}} i^{*} d \Gamma+\sum_{k=1}^{n_{a}} \int_{\Gamma_{a}^{k}} \phi^{k}\left(\xi_{x}, \xi_{y}, \theta_{x}, \theta_{y}\right) i^{*} d \Gamma \\
= & \sum_{j=1}^{n_{o}} i^{j} \int_{\Gamma_{o}^{j}} \phi^{*} d \Gamma+\sum_{k=1}^{n_{a}} \int_{\Gamma_{a}^{k}} i^{k}\left(\xi_{x}, \xi_{y}, \theta_{x}, \theta_{y}\right) \phi^{*} d \Gamma
\end{aligned}
$$

ここで, 上添字 $i$ は $i$ 番目のソース点を表し, $j$ は $j$ 番 目の通常要素を表し, $k$ は $k$ 番目の網目要素を表す.

これらの式から次の方程式が得られる.

$$
[H]\left\{\begin{array}{c}
\phi^{j} \\
I_{s} \\
Q_{e}^{1 \sim 6}
\end{array}\right\}+\{\boldsymbol{b}\}=[G]\left\{\begin{array}{c}
i^{j} \\
I_{s} \\
Q_{e}^{1 \sim 6}
\end{array}\right\}
$$

ここで, $[H]$ および $[G]$ は解析対象の形状と直線近 似した分極曲線の勾配によって決まる行列でありり， $\phi^{j}$ および $i^{j}\left(j=1,2, \ldots, n_{o}\right)$ はそれぞれ $j$ 番目の通常要素 の電位および電流密度を表す. $\boldsymbol{b}$ は直線近似した分極 曲線の切片に関連した定数ベクトルである.Iおよび $Q^{1 \sim 6}$ は式 (9) および (10)における網目要素の未知パ ラメータである. 下添字 $s\left(=1,2, \ldots, n_{s} ; n_{s}\right.$ は網目要素 の全節点数) は $s$ 番目の網目節点番号である.下添字 $e\left(e=1,2, \ldots, n_{a}\right)$ は $e$ 番目の網目要素を表す.

末知数の数と方程式数は次の通りである. 通常要素 では, 未知数の数は要素数と同じ $n_{o}$ 個である. 通常
要素上にはそれぞれ1つのソース点を置くことによ り方程式を $n_{o}$ 個作る. 網目要素上における未知数の 数は, 仮想節点の值を表す $I_{s}$ が $n_{s}$ 個, 各網目要素内 の軸に沿った方向の電流密度変化を表現する $Q_{e}^{1}$ 及び $Q_{e}^{2}$ が $2 n_{a}$ 個, および軸の周方向の電流密度変化を表 現する $Q_{e}^{3} \sim Q_{e}^{6}$ が $4 n_{a}$ 個であるから, 未知数の合計は $n_{s}+6 n_{a}$ 個である.

各網目要素にソース点を 10 個置けば方程式の数 が $10 n_{a}$ 個となり, $n_{s} \leq 4 n_{a}$ であるので, 未知数の数 $n_{s}+6 n_{a}$ 個以上になる. そこで, 網目要素内ではソース 点を網目上にバランス良く 10 個置き, Newton-Raphson 法により連立方程式 (19)を解く. 方程式数が末知数の 数より多いので, Newton-Raphson 法で繰り返し解の 修正量を求める際に，最小 2 乗法を用いる.

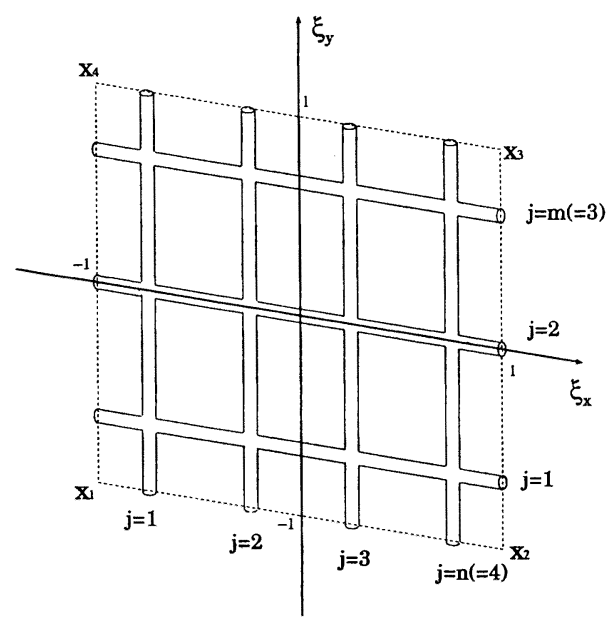

Fig. 3 Local coordinate

\section{5. 網目要素に関する積分}

式(19)の $[H]$ および $[G]$ の要素を求めるために, 式 (17) および (18) の積分を実行する. 観測点か網目要素 上以外にある場合は, 通常の方法に従い, 観測点 $x$ が 網目要素上にある場合には, 次のようにして求める. まず式 (17) および (18) の左辺第 3 項は, 網目要素を $\xi_{x}$ 軸に平行な軸と $\xi_{y}$ 軸に平行な軸に分けて考える. 図 3 のように軸番号を定め, 次式のようにして積分を実 行する. ただし, 中点 $(\cdot)$ は内積を表す.

$$
\begin{aligned}
& \int_{\Gamma_{a}} \phi^{l}\left(\xi_{x}, \xi_{y}, \theta_{x}, \theta_{y}\right) i^{*} d \Gamma \\
= & \sum_{j=1}^{m} \int_{-1}^{1} \int_{-\pi}^{\pi} \phi^{l}\left(\xi_{x}, \theta_{x}\right) \frac{-\kappa r_{x} \cdot n_{x}}{4 \pi r_{x}^{3}} \frac{R L_{x}}{2} d \theta_{x} d \xi_{x} \\
+ & \sum_{j=1}^{n} \int_{-1}^{1} \int_{-\pi}^{\pi} \phi^{l}\left(\xi_{y}, \theta_{y}\right) \frac{-\kappa r_{y} \cdot n_{y}}{4 \pi r_{y}^{3}} \frac{R L_{y}}{2} d \theta_{y} d \xi_{y}
\end{aligned}
$$


同様に, 式 (17) および (18) の右辺第 2 項は次式のよ うに書かれる.

$$
\begin{aligned}
& \int_{\Gamma_{a}} i^{l}\left(\xi_{x}, \xi_{y}, \theta_{x}, \theta_{y}\right) i^{*} d \Gamma \\
= & \sum_{j=1}^{m} \int_{-1}^{1} \int_{-\pi}^{\pi} i^{l}\left(\xi_{x}, \theta_{x}\right) \frac{1}{4 \pi r_{x}} \frac{R L_{x}}{2} d \theta_{x} d \xi_{x} \\
+ & \sum_{j=1}^{n} \int_{-1}^{1} \int_{-\pi}^{\pi} i^{l}\left(\xi_{y}, \theta_{y}\right) \frac{1}{4 \pi r_{y}} \frac{R L_{y}}{2} d \theta_{y} d \xi_{y}
\end{aligned}
$$

ここで, $r_{x}$ および $r_{y}$ は, ソース点からそれぞれの軸 上にある観測点までのベクトルであり， $r_{x}$ および $r_{y}$ は その長さである. $n_{x}$ および $n_{y}$ は，それぞれの軸上の 観測点における単位外向き法線ベクトルであり，Rは 軸の半径， $L_{x}$ および $L_{y}$ はそれぞれ網目要素の $x$ 方向 および $y$ 方向の長さである.

さらに, 網目要素上に設けた座標系でソース点の座 標が

$$
\boldsymbol{x}_{s}=\left(x_{s}, y_{s}, z_{s}\right)
$$

であるすると, $\boldsymbol{r}_{x}, \boldsymbol{r}_{x}$ および $\boldsymbol{n}_{x}, \boldsymbol{n}_{x}$ は，以下のように表 すことが出来る.

$$
\begin{aligned}
& \boldsymbol{r}_{x}=\left\{\begin{array}{c}
\frac{L_{x}}{2} \xi_{x}-x_{s} \\
\left.\left(-\frac{m+1}{2}+j\right) \frac{L_{y}}{m}+R \sin \theta_{x}-y_{s}\right\} \\
R \cos \theta_{x}-z_{s}
\end{array}\right\} \\
& \boldsymbol{r}_{y}=\left\{\begin{array}{c}
\left(-\frac{n+1}{2}+j\right) \frac{L_{x}}{n}-R \sin \theta_{y}-x_{s} \\
\frac{L_{y}}{2} \xi_{y}-y_{s} \\
R \cos \theta_{y}-z_{s}
\end{array}\right\} \\
& \boldsymbol{n}_{x}=\left\{\begin{array}{c}
0 \\
-\sin \theta_{x} \\
-\cos \theta_{x}
\end{array}\right\}, \quad \boldsymbol{n}_{y}=\left\{\begin{array}{c}
\sin \theta_{y} \\
0 \\
-\cos \theta_{y}
\end{array}\right\}
\end{aligned}
$$

式 (23)，(24) および (25) を式 (20) および (21) に代 入し, 数值積分を行う. その際ソース点 $y$ と観測点 $x$ が同一の網目要素にある場合には，これらの積分はい ずれも $\mathrm{O}(1 / \mathrm{r})$ の特異性を持つ.そこで,ソース点と観 測点が同一の網目要素にある場合には, Lachat の方法 （3）を用いて特異性を緩和した後に Gauss の積分公式 を用いる. そうでない場合には, 直接 Gauss の積分公 式を用いる.

なお，以上では，網目形状部が金属である場合，す なわち分極曲線が指定された場合について述べたが, 電流密度指定または電位指定の場合には, 電流密度だ けでなく電位も式 (9) および (10) と同じょうにフー リエ級数を用いて表す. 電流密度指定の場合は, 1 つ の網目要素当たり 10 個のパラメータ $\left(I\right.$ および $\left.Q^{1 \sim 6}\right)$ が指定されているので, 電位の ( 1 つの網目要素当た り)10 個のパラメータが末知数となる. ソース点を 1
つの網目要素当たり 10 個設ければ, 分極曲線指定の 場合と同様にして, 電位の未知パラメータを求めるこ とができる．電位指定の場合も同様である.

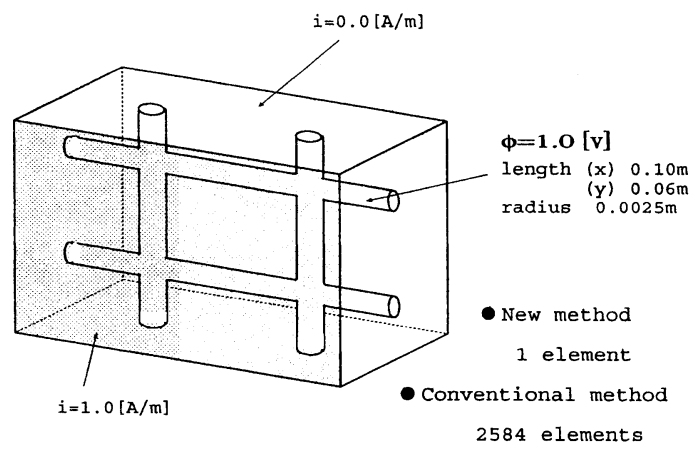

Fig. 4 Small net

6. 検 証

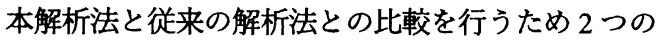
例題について述べる. まず, 網目の軸方向および周方 向ともに電流密度変化が大きくなるモデルによって本 解析法と従来の解析法との比較を行う. 次に, やや小 さな鉄筋コンクリートのブロックを模したモデルに対 して, 本解析法と従来の解析法との比較を行う.

6.1 モデ 1 (井柯) 図 4 のように縱および 横方向の円柱 2 本により構成される網目形状構造物 (井桁) を考六る. 長方形の網目構造物の軸の長さは それぞれ $0.1[\mathrm{~m}]$ および $0.06[\mathrm{~m}]$ であり, 軸の直径は $5[\mathrm{~mm}]$ である. この網目構造物を図 4 に示すような $0.04[\mathrm{~m}] \times 0.06[\mathrm{~m}] \times 0.1[\mathrm{~m}]$ の直方体の溶液中に置く.こ の溶液の電気伝導度 $\kappa$ を $0.01\left[\Omega^{-1} \mathrm{~m}^{-1}\right]$ とし, 直方体 の 1 つの面から電流密度 $i=1.0\left[\mathrm{~A} / \mathrm{m}^{2}\right]$ の電流を流し, 残りの 5 面は絶縁 $\left(i=0.0\left[\mathrm{~A} / \mathrm{m}^{2}\right]\right)$ とした。 また, 網目 構造物表面の境界条件は電位 $\phi=1.0[\mathrm{~V}]$ を指定した。

本手法による解析法では網目構造物を 1 つの網目要 素で表し, 網目構造物を囲む直方体部分は一定要素で 2686 要素に分割した. 従来の境界要素法を用いた解析 には 4 角形一定要素を用い，この網目構造物を 2584 要素に分割し，網目構造物を囲む直方体部分は本手法 の場合と同様に, 2686 要素に分割した.

図 5 に網目構造物の長い方の軸の表面における軸 方向の電流密度分布を示す.また, 図 6 に網目構造物 の $x=0[\mathrm{~m}]$ における軸の周方向の電流密度分布を示 す. 本手法と従来法の結果は良く一致していることが わかる.

6.2 モデル2（敘筋コンクリートブロック） 図 7 のように 8 本の鉄筋が中心に埋め込まれた一辺の長 


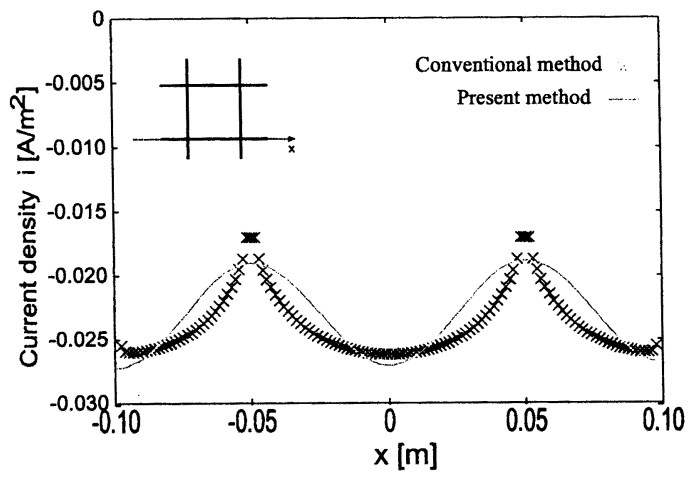

Fig. 5 Current density along a bar

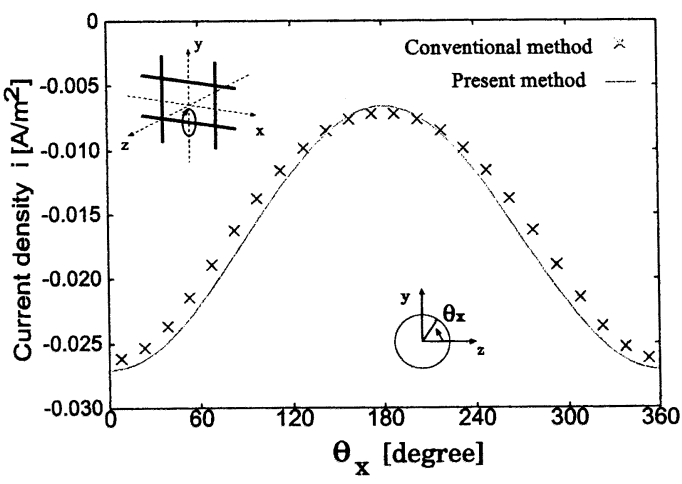

Fig. 6 Circumfencial distribution of current density

さが $0.2[\mathrm{~m}]$ の立方体の鉄筋コンクリートブロックを 外部電源方式によりカソード防食する場合を考える. 軸の直径は $4[\mathrm{~mm}]$ である.コンクリートの電気伝導 度 $\kappa$ は $0.007\left[\Omega^{-1} m^{-1}\right]$ とした。コンクリートの表面 のうち網に平行な 1 つの面をカソード防食用の電極と し電流密度 $i=0.02\left[\mathrm{~A} / \mathrm{m}^{2}\right]$ の電流を流し, 残りの 5 面は 絶縁 $\left(i=0.0\left[\mathrm{~A} / \mathrm{mi}^{2}\right]\right)$ とした r. また，鉄筋の分極曲線を $\phi=-9.23 i+0.596[\mathrm{~V}]$ とした.

本手法による解析では網目状の鉄筋を 4 つの網目要 素で分割し，コンクリート表面は 600 個の一定要素で 分割した. このモデルでは, 網目の軸の周方向電流密 度変化は小さいと予想されるので, 周方向の電流密度 は一定とした. すなわち, $Q_{3}=Q_{4}=Q_{5}=Q_{6}=0$ と した. 一方, 従来法による解析では, 周方向の電流密 度が一定であると仮定するパイプ要素を用いて 320 要 素に分割した．なお，コンクリート表面は本手法の場 合と同様に 600 個の 4 角形一定要素で分割した。

図 8 に中央よりの軸の表面における $x$ 方向電流密度 分布を示す. 本研究の要素で従来法と同程度に電流密

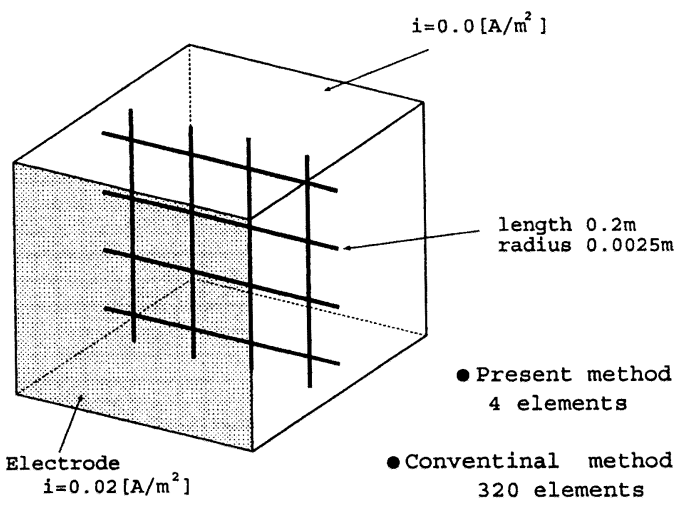

Fig. 7 Reinforced concrete block

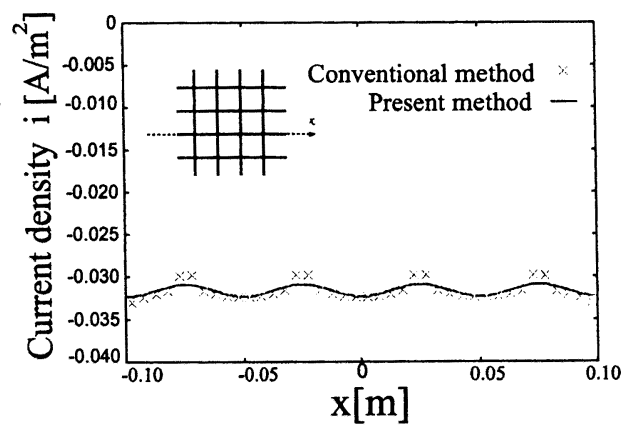

Fig. 8 Current density distribution on steel rebar

度分布が表現できていることがわかる。

\section{7. 解析例 (鉄筋コンクリート柱)}

図 9 のような外部電源方式のカソード防食を施し た鉄筋コンクリート柱を考える. 柱の長さは $1[\mathrm{~m}]$, 半径は $0.15[\mathrm{~m}]$ である. 直径 $4[\mathrm{~mm}]$ の鉄筋が半径 $0.10[\mathrm{~m}]$ の位置に埋め込まれているものとする. 電極 は $0.02[\mathrm{~m}] \times 0.02[\mathrm{~m}] \times 0.30[\mathrm{~m}]$ で柱の中央部に埋め込 まれている. 鉄筋の分極曲線を $\phi=-9.23 i+0.596[\mathrm{~V}]$ とし，コンクリートの電気伝導度 $\kappa$ を $0.007\left[\Omega^{-1} \mathrm{~m}^{-1}\right]$ とした。

対称性から，柱の上半分を 90 度分だけ要素分割し た. 図 10 に鉄筋部分の要素分割を示す．鉄筋部分は 柱の軸方向に 10 個, 周方向に 3 個の合計 30 個の網目 要素を用いて要素分割した．各網目要素内の鉄筋数は 縱横 2 本づつである.

コンクリート表面および分割面は 1780 個の 4 角形 一定要素で分割し，絶縁条件 $i=0.0\left[\mathrm{~A} / \mathrm{m}^{2}\right]$ を課した。 ま た, 中央の電極は 62 個の 4 角形一定要素で分割し，一 


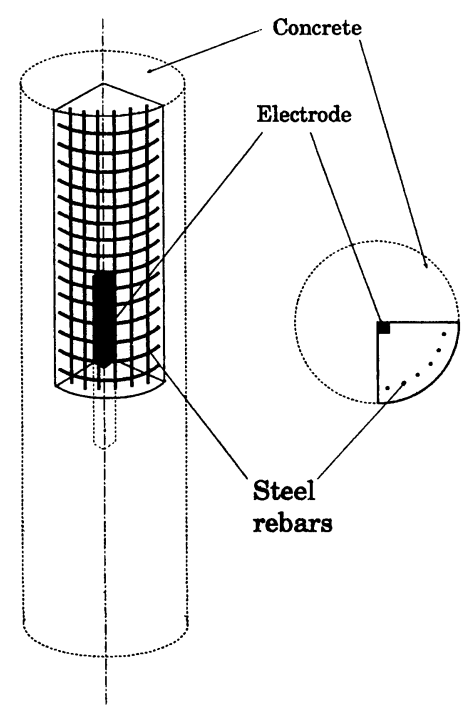

Fig. 9 Reinforced concrete pillar

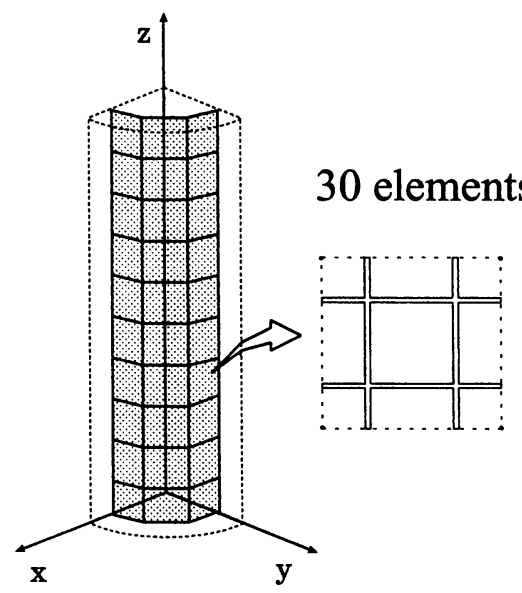

Fig. 10 Discretization of rebars with net elements

定の電流密度 $i=1.0\left[\mathrm{~A} / \mathrm{m}^{2}\right]$ を指定した.

図 11 に鉄筋上の $\mathrm{z}$ 方向の電流密度分布を示す. 本 手法はこのような問題を解析するのに有効であること がわかる.

\section{8. 結 官}

本研究では通常の境界要素法をそのまま用いると, 要素数が膨大となり解析が困難であった網目状構造物 の腐食解析を行なう手法を開発した.すすなわ，網目 形状部で電位および電流密度が網の軸方向および周方 向に周期的に変化することに着目した網目要素を開発 することにより解析に必要な要素数を大幅に減らした。

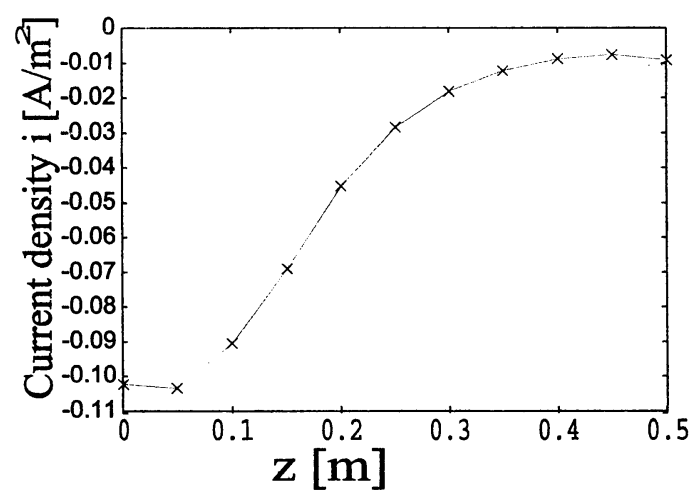

Fig. 11 Potential distribution on rebars

また, 従来法との比較により本手法の精度を確認する とともに，鉄筋コンクリート柱の腐食解析を行ない, 本手法の有効性を示した. なお, 本報では網の金属の 分極曲線を直線近似したが，曲線のまま取扱えるよう に改良することを今後の課題としたい.

\section{文献}

(1) C.A.Brebbia,The Boundary Element Method for Engineers,Pentech Press,(1978) (translated into Japanese by N.Kamiya et al.),Baihuukan,(1980),pp.1-178

(2) N.Tosaka, T.Nakayama,Foundations of The Boundary Element Method, Nikkajiren Publishing,(1987), pp.1-239

(3) M.Tanaka, T.Matsumoto, M.Nakamura, The Boundary Element Method, Baihuukan,(1994), pp.1-347

(4) N.G.Zamani, J.F.Porter, A.A.Mufti, $A$ Survey of Computational Efforts in the Field of Collosion Engineering, Int. J. Numer. Methods Eng., Vol.23, (1986), pp.1295.-1311

(5) R.A.Adey, C.A.Brebbia, S. M.Niku, Application of Boundary Elements in Corrosion Engineering, Topics in Boundary Element Research VII (ed. C.A.Brebbia), Springer-Verlag (1990), pp.34-64

(6) M.E.Orazem, J.M.Esteban, K.J.Kennelley, R.M.Degerstedt, Mathematical Models for Cathodic Protection of an Underground Pipeline with Coating Holidays:Part 1-Theoretical Development, Corrosion, Vol.53, No.4, (1997), pp.264-272

(7) S.Aoki, K.Amaya, M.Miyasaka , Boundary Element Analysis on Corrosion Problems, Syokabo, (1998) pp.1200

(8) K.Amaya et al., An Efficient Boundary Element Method for Non-axisymmetric Three-Dimmensional Corrosion Problems, Trans.Japan Soc. Civil Eng.(Applied Mechanics), Vol.2, (1999), pp.177-184

(9) M.Ridha, K.Amaya and S.Aoki, Boundary Element Simulation for Identification of Steel Corrosion in Concrete Using Magnetic Field Measurement, Corrosion, Vol.61, No.8, (2005), pp.784-791 